\title{
KEDUDUKAN BASYARNAS DALAM PENANGANAN KEPAILITAN PERBANKAN SYARIAH DITINJAU DARI UU NO. 21 TAHUN 2008 TENTANG PERBANKAN SYARIAH
}

\author{
Ephin Apriyandanu \\ Magister Hukum Universitas Semarang
}

\begin{abstract}
ABSTRAK
Penelitian ini bertujuan untuk mempelajari dan menganalisa kedudukan Badan Arbitrase Syariah Nasional (BASYARNAS) yang mempunyai kewenangan untuk menyelesaikan sengketa bisnis syariah. BASYARNAS memiliki hukum acara arbitrase sendiri yang dapat dijadikan pilihan hukum bagi para pihak yang bersengketa yang diatur dalam Peraturan Prosedur BASYARNAS. Akan tetapi, untuk mengajukan penyelesaian kepailitan melalui BASYARNAS, pemohon harus tetap berdasarkan klausula arbitrase atau perjanjian arbitrase. Adapun masalah dalam penelitian ini adalah dasar hukum BASYARNAS dalam menyelesaikan kepailitan, serta faktor penunjang dan penghambat dalam penyelesaian kepailitan melalui BASYARNAS. Penelitian ini adalah penelitian yuridis normatif dengan tipe penelitian deduktif. Hasil penelitian menunjukan bahwa dasar hukum yang dipakai dalam penyelesaian kepailitan melalui BASYARNAS yaitu hukum Islam dan hukum nasional. Peraturan Prosedur BASYARNAS mengatur dasar hukum yang digunakan yaitu Al-Qur'an, AsSunnah, Ijma', Undang-Undang No. 30 Tahun 1999 tentang Arbitrase dan Alternatif Penyelesaian Sengketa, SK MUI, dan Fatwa DSN-MUI. Para pihak yang telah sepakat untuk menyelesaikan sengketanya di BASYARNAS maka akan diselesaikan dan diputus menurut peraturan prosedur BASYARNAS. Peraturan dalam menyelesaikan kepailitan melalui BASYARNAS belum jelas karena belum diatur dalam UndangUndang No. 21 Tahun 2008 tentang Perbankan Syariah. Faktor penunjang dalam menyelesaikan kepailitan melalui BASYARNAS yaitu para arbiter. BASYARNAS adalah arbiter yang berkompeten dalam bidangnya.
\end{abstract}

Kata Kunci : Basyarnas; kepailitan; perbankan syariah 


\title{
THE POSITION OF BASYARNAS IN MANAGEMENT OF SHARIA BANKING BANKRUPTCY IS REVIEWED FROM LAW NO. 21 OF 2008 CONCERNING SHARIA BANKING
}

\author{
Ephin Apriyandanu \\ Master of Law, University of Semarang
}

\begin{abstract}
This research aims to study and analyze the position National Sharia Arbitration Board (BASYARNAS) is one of the arbitration institutions that has the authority to resolve the sharia businessdispute. BASYARNAS own it arbitration procedural law thatcan be the legal choice for the parties which arranged in the BASYARNAS Procedural Rules. However, to file a bankruptcy settlement through BASYARNAS, the petitionershould be underon the arbitration clause or arbitration agreement. The issue in this research is BASYARNAS legal basis in resolve bankruptcy, as well as supporting and inhibiting factors of bankruptcy settlement through BASYARNAS. This is normative juridical research with deductive research type. The research result show that the legal basis used in bankruptcy settlement through BASYARNAS is Islamic law and national law. The BASYARNAS Procedural Rules regulate the legal basis used that isQur'an, As-Sunnah, Ijma ', Law No. 30 of 1999 on Arbitration and Alternative Dispute Resolution, MUI Decree, and Fatwa DSN-MUI. The parties who agree to settle the dispute in BASYARNAS will be resolved and decided under BASYARNAS procedure rules. The bankruptcy resolving regulation through BASYARNAS is not clear yet because it is not regulated in Law No. 21 of 2008 on Sharia Banking. The supporting factor in solving bankruptcy through BASYARNAS is the arbitrators. BASYARNAS is a competent arbitrator in this field. While the inhibiting factors BASYARNAS among them is the obscurity of Law No. 21 of 2008 on Sharia Banking in regulating bankruptcy, until now bankruptcy only regulated in Law No. 37 of 2004 on Bankruptcy. The solution required is the settlement of Law No. 21 of 2008 which regulates bankruptcy settlement through BASYARNAS, BASYARNAS may need to prepare Human Resources that are ready to handle bankruptcy, and most important is the renewal of Law No. 21 of 2008 to provide the role to BASYARNAS in bankruptcy handling.
\end{abstract}

Keywords: Basyarnas; bankruptcy; sharia banking. 


\section{A. PENDAHULUAN}

Perbankan syarieeah dewasa ini menunjukkan kecenderungan yang semakin baik. Produk-produk yang dikeluarkan bank syarieeah cukup bervariatif sehingga mampu memberikan pilihan/alternatif bagi calon nasabah untuk memanfaatkannya dimana hal ini hampir sama dengan bank konvensional. ${ }^{1}$

Basyarnas merupakan kepanjangan dari "BADAN ARBITRASE SYARIAH NASIONAL". Undang-Undang No.30 Tahun 1999 tentang Arbitrase dan Alternatif Penyelesaian Sengketa, dirumuskan dalam BAB I pasal 1 ayat (1) Bahwa Arbitrase adalah cara penyelesaian suatu sengketa perdata di luar peradilan umum yang didasarkan pada perjanjian arbitrase yang dibuat secara tertulis oleh para pihak yang bersengketa.

Secara istilah Arbitrase adalah penyelesaian sengketa yang dilakukan oleh seorang atau beberapa orang arbiter atas dasar kebijaksanaannya dan para pihak akan tunduk pada putusan yang diberikan oleh arbiter yang mereka tunjuk. $^{2}$

Setelah diberlakukannya Undang-Undang No. 21 Tahun 2008 tentang Perbankan Syariah yang terbit tanggal 16 Juli 2008, maka pengembangan industri perbankan syariah nasional semakin memiliki landasan hukum yang memadai dan akan mendorong pertumbuhannya secara lebih cepat lagi.

Mengingat begitu pentingnya fungsi dan peranan perbankan syariah di Indonesia, maka pihak bank syariah perlu meningkatkan kinerjanya agar tercipta perbankan dengan prinsip syariah dan efisien. Profitibalitas merupakan indikator yang paling tepat untuk mengukur kinerja suatu bank. Return On Asset (ROA) merupakan salah satu rasio profitabilitas yang

${ }^{1}$ Abdul Ghoni, Implementasi Penyelesaian

Hukum Atas Eksekusi Jaminan Dalam Perbankan Syariah, Jurnal Ius Constituendum Vol 1 No 1, Magister Hukum Universitas Semarang, 2016, Semarang, hlm 60.

${ }^{2}$ Ahmad Djauhari, Arbitrase Syari'ah di Indonesia, (Jakarta: Basyarnas, 2006), hlm.22. 
digunakan untuk mengukur efektifitas perusahaan dalam menghasilkan keuntungan dengan memanfaatkan total aktiva yang dimilikinya. ${ }^{3}$

Badan Arbitrase Syariah Nasional (Basyarnas) adalah sebuah wadah alternatif diluar pengadilan (non-litigasi) di dalam penyelesaian sengketa atau perkara di perbankan syariah dan Lembaga Keuangan Syariah (LKS) lainnya. Keberadaan Basyarnas saat ini sangat dibutuhkan oleh umat Islam Indonesia, terlebih dengan semakin marak dan berkembangnya perusahaan perbankan dan keuangan syariah di Indonesia dewasa ini. Pertumbuhan ekonomi dan bisnis syariah yang pesat dan kompleks seperti saat ini pasti melahirkan berbagai macam bentuk kerjasama atau transaksi bisnis.

Berkaitan dengan itu, Basyarnas yang sebelumnya bernama Badan Arbitrase Muamalat Indonesia (BAMUI), yang menandai kehadiran lembaga arbitrase Islam pertama kali di Indonesia dan Basyarnas sendiri merupakan salah satu perangkat dari organisasi MUI.

\section{B. PERMaSAlahan}

1. Bagaimanakah kedudukan BASYARNAS dalam mengatasi kepailitan oleh perbankan syariah sesuai dengan UU No. 21 Tahun 2008 ?

2. Bagaimana kendala dan solusi yang dihadapi BASYARNAS dalam menyelesaikan kepailitan sesuai UU No. 21 Tahun 2008 ?

\section{PEMBAHASAN}

\section{KEDUDUKAN BASYARNAS DALAM MENGATASI KEPAILITAN OLEH PERBANKAN SYARIAH}

Pasal 1338 KUHP menyatakan bahwa "semua perjanjian yang dibuat sesuai dengan undang-undang berlaku sebagai undang-undang bagi mereka yang membuatnya". Perjanjian tersebut tidak dapat ditarik kembali selain dari pada kesepakatan antara kedua belah pihak atau karena hal lain yang telah ditentukan oleh Undang-Undang.

Berdasarkan penjelasan pasal diatas maka seluruh ahli hukum sepakat untuk menyimpulkan bahwa dalam hal hukum perjanjian, hukum positif

${ }^{3}$ Martono, Bank dan Lembaga Keuangan Lain, (Yogyakarta:Ekonisia, 2004), hlm.84-86. 
yang berlaku di Indonesia menganut sistem terbuka yang berarti setiap orang bebas untuk membuat perjanjian asalkan perjanjian tersebut dibuat sesuai dengan undang-undang dan tidak melanggar ketertiban umum, norma dan kesusilaan. Selain itu, para pihak juga bebas untuk meyelesaikan perselisihan yang terjadi.

Arbitrase dapat berperan sebagai pengganti badan peradilan dalam menyelesaikan sengketa perdata antara para pihak yang disebabkan terjadinya wanprestasi, tapi pertanyaannya apakah kewenangan arbitrase juga dapat menggantikan peran proses kepailitan yang notabene berhubungan dengan status personal seseorang atau badan hukum.

Undang-Undang Perbankan Syariah dengan Undang-Undang Kepailitan merupakan 2 (dua) Undang-Undang yang berbeda, karena pada dasarnya Undang-Undang Perbankan Syariah hanya mengatur tentang tata cara penyelesaian sengketa dengan garis besar adalah di Pengadilan Agama, namun apabila para pihak telah memperjanjikan penyelesaian sengketa maka penyelesaian sengketa dilakukan sesuai dengan isi Akad sesuai dengan pasal 55 ayat 2 Undang-Undang No 21 tahun 2008 Tentang Perbankan Syariah.

Undang-Undang Perbankan Syariah sebenarnya kurang menjabarkan tentang bagaimana proses penyelesaian secara detail, serta siapa saja yang termasuk didalam ruang lingkup Perbankan Syariah. Perjanjian arbitrase yang lazim disebut "klausula arbitrase" merupakan perjanjian tambahan yang melekat pada perjanjian pokoknya. ${ }^{4}$

Sementara kedudukan Basyarnas sendiri hanya sebatas mengatur tentang Abitrase dimana pada Undang-Undang Perbankan Syariah belum mengatur secara tegas tentang abitrase seperti yang terdapat pada pasal 55 ayat 2 Undang-Undang No. 21 tahun 2008 Tentang Perbankan Syariah. Pada pasal tersebut hanya menjelaskan tentang penyelesaian dilakukan sesuai dengan Isi Akad.

\footnotetext{
${ }^{4}$ Asep Saepudin Jahar (et al), Hukum Keluarga, Pidana, dan Bisnis, Penerbit: Kencana Prenadamedia Group, Jakarta, 2013, hlm 47.
} 
Isi Akad disini dapat diartikan sebagai isi perjanjian yang dilakukan oleh kedua belah pihak yang mencapai kesepakatan bahwasanya apabila terdapat suatu masalah akan diselesaiakan diluar pengadilan. Namun apabila dalam hal ini tidak dijelaskan secara terperinci maka para pihak juga akan merasa kebingungan dengan penyelesaian diluar pengadilan.

Adanya perjanjian arbitrase maka peran basyarnas dalam menyelesaikan sengketa perbankan syariah baru dapat dilaksanakan karena basyarnas memiliki kewenangan absolut untuk menyelesaikan permasalahan yang terjadi. Terhadap adanya kewenangan absolut Peradilan Agama untuk menyelesaikan sengketa yang terjadi dalam sengketa perbankan syariah maka kewenangan Pengadilan Agama tersebut tidak berlaku lagi.

\section{KENDALA DAN SOLUSI YANG DIHADAPI BASYARNAS DALAM MENYELESAIKAN KEPAILITAN SESUAI UU NO. 21 TAHUN 2008}

Pasal 55 ayat (2) Undang-Undang 21 Tahun 2008 justru membuka peluang untuk diselesaikannya penyelesaian sengketa perbankan syariah melalui penyelesaian sengketa di luar pengadilan salah satunya adalah melalui arbitrase dan Mengesampingkan kewenangan Pengadilan Agama dalam penyelesaian sengketa perbankan syariah sebagaimana ditegaskan dalam Pasal 55 ayat (1) Undang-Undang 21 Tahun 2008.

Menurut Pasal 1 butir 1 Undang-Undang No. 30 Tahun 1999 arbitrase adalah cara penyelesaian suatu sengketa perdata di luar peradilan umum yang didasarkan pada perjanjian arbitrase yang dibuat secara tertulis oleh para pihak yang bersengketa. Berdasarkan definisi ini dapat dipahami bahwa suatu sengketa dapat diselesaikan melalui arbitrase apabila para pihak yang bersengketa sepakat bersama-sama terhadap pilihan tersebut dan menuangkan kesepakatan itu secara tertulis. Pada prinsipnya, kesepakatan tersebut bisa dibuat dalam bentuk klausa arbitrase sebelum timbulnya sengketa (pactum compromittendo) atau kesepakatan arbitrase secara tertulis yang dibuat terpisah setelah munculnya sengketa (acta 
compromise). Penting untuk dicatat, ketika para pihak yang bersengketa telah sepakat menyelesaikan sengketanya melalui arbitrase, maka mereka secara sadar telah melepaskan haknya untuk membawa sengketa mereka ke lembaga peradilan.

Selain apa yang dijelaskan di atas penyelesaian kepailitan melalui arbitrase ini menemui beberapa permasalahan. Basyarnas sebagai lembaga yang memiliki Legal Standing sesuai dengan Undang-Undang No. 21 Tahun 2008 belum dapat dikatakan menangani kepailitan mengingat ketentuan pokok yang ada didalam Undang-Undang Perbankan Syariah.

Undang-Undang Perbankan Syariah belum mengatur secara jelas dan spesifik terkait penyelesaian kepailitan, hal ini yang diatur dalam UndangUndang No. 21 tahun 2008 hanya berkisar masalah penyelesaian sengketa. Pada sisi lain ketentuan ini menjadikan terjadinya kekosongan hukum (vacum of law) sehingga menimbulkan ketidakpastian dalam sistem perbankan syariah yang di implementasikan pasca terbentuknya UndangUndang No. 21 Tahun 2008, dalam kedudukan yang demikian basyarnas dianggap pihak yang tidak berwenang menangani masalah kepailitan apabila terjadi pada Perbankan Syariah.

Kewenangan Badan Arbitrase Syariah Nasional secara peraturan perundang-undangan masih memakai Undang-Undang Nomor 30 Tahun 1999 tentang Arbitrase dan Pilihan Penyelesaian Sengketa. Hal ini tidak sesuai dengan apa yang menjadi tugas dari Badan Arbitrase Syariah Nasional yang mempunyai tugas menyelesaikan sengketa-sengketa Arbitrase di bidang ekonomi syariah.

Terkait dengan kompetensi absolut Badan Arbitrase Syariah Nasional (Basyarnas) yang didasarkan pada perjanjian atau klausul penyelesaian sengketa melalui Badan Arbitrase Syariah Nasional (Basyarnas) yang telah disepakati oleh para pihak, maka hal tersebut tidak menutup kemungkinan bagi pihak non muslim atau lembaga keuangan non-syariah untuk dapat menyelesaikan sengketanya melalui Badan Arbitrase Syariah Nasional 
(Basyarnas) selama hal tersebut telah diperjanjikan oleh pihak yang bersangkutan.

\section{PENUTUP}

Kedudukan Basyarnas dalam menyelesaikan kepailitan belum diatur dalam Undang-Undang No. 21 Tahun 2008 Tentang Perbankan Syariah, namun dalam praktiknya hal tersebut masih bersifat umum sehingga membutuhkan instrument peraturan lain diantaranya Undang-Undang No. 37 Tahun 2004 Tentang Kepailitan dan Penundaan Kewajiban Pembayaran Utang (PKPU) dan Undang-Undang No. 40 tahun 2007 Tentang Perseroan Terbatas (PT), hal ini menjadi salah satu kendala dalam penjelasan kepailitan pada Perbankan Syariah yang dihadapi Basyarnas. Basyarnas sebagai lembaga yang memiliki Legal Standing sesuai dengan Undang-Undang No. 21 Tahun 2008 belum dapat dikatakan menangani kepailitan mengingat ketentuan pokok yang ada didalam Undang-Undang Perbankan Syariah. Undang-Undang Perbankan Syariah belum mengatur secara jelas dan spesifik terkait penyelesaian kepailitan, hal ini yang diatur dalam Undang-Undang No. 21 tahun 2008 hanya berkisar masalah penyelesaian sengketa. 


\section{DAFTAR PUSTAKA}

\section{Buku}

Abdul Ghofur Anshori. 2009. Perbankan Syariah Di Indonesia. cetakan ke2, Yogyakarta : Gadjah Mada University Press.

Adrian Sutedi. 2009. Perbankan Syariah Tinjauan Dari Beberapa Segi Hukum. Bogor: Ghalia Indonesia.

Cik Basir. 2009. Penyelesaian Sengketa Perbankan Syariah: Di Pengadilan Agama \& Mahkamah Syariah. cet. Ke-1 Jakarta: Kencana.

Gatot Soemartono. 2002. Arbitrase dan Mediasi di Indonesia. Jakarta : PT. Gramedia.

Mariam Darus Badrulzaman. 1994. Peranan BAMUI dalam Pembangunan Hukum Nasional dalam Arbitrase Islam di Indonesia. Jakarta : BAMUI dan Muamalat.

Rachmadi Usman. 2013. Pilihan Penyelesaian Sengketa di Luar Pengadilan. Bandung : Citra Aditya Bakti.

\section{Jurnal}

Abdul Ghoni, Implementasi Penyelesaian Hukum Atas Eksekusi Jaminan Dalam Perbankan Syariah, Jurnal Ius Constituendum Vol 1 No 1, Magister Hukum Universitas Semarang, 2016, Semarang. http://dx.doi.org/10.26623/jic.v1i2.551

\section{Undang - Undang}

1) Undang-Undang Dasar Negara Republik Indonesia Tahun 1945.

2) Undang-Undang Nomor 21 Tahun 2008 Tentang Perbankan Syariah.

3) Undang-Undang Nomor 37 Tahun 2004 tentang Kepailitan dan Penundaan Kewajiban Pembayaran Utang.

4) PERMA No. 2 Tahun 2008 tentang Kompilasi Hukum Ekonomi Syariah.

5) Undang-Undang Nomor 30 Tahun 1999 Tentang Arbitrase. 